RETRACTED

\title{
PERANAN “INCAR” (INFORMASI CERDAS ALA REMAJA) DALAM PROGRAM GENRE (GENERASI BERENCANA) DI KABUPATEN NUNUKAN
}

\section{THE ROLE OF “INCAR” (SMART INFORMATION FOR TEENAGERS) IN THE "GENRE” (GENERATION PLAN) PROGRAM IN NUNUKAN DISTRICT}

\author{
Tri Noor Aziza dan Itcianday \\ PKP2A III Lembaga Administrasi Negara \\ J1. H.M. Ardans Ringroad 3 Samarinda \\ e-mail : iza.aziza@gmail.com; itci_sh@yahoo.com
}

Naskah diterima: 2 Agustus 2018; revisi terakhir: 22 Oktober 2018; disetujui: 8 November 2018

\section{Retracted}

Following a rigorous and careful concerns and consideration in the review of the article published in Jurnal Borneo Administrator entitled "Peranan "INCAR" (Informasi Cerdas Ala Remaja) dalam Program Genre (Generasi Berencana) di Kabupaten Nunukan" Vol. 14, No. 3, pp. 171-188, Desember 2018, DOI: http://doi.org/10.24258/jba.v14i3.364.

This paper has been found to violate the principles of Jurnal Borneo Administrator Publication and has been retracted.

The article has contained redundant material and throughout a careful examination, the editor has found that the paper has also been published in Jurnal Kesejahteraan Keluarga dan Pendidikan, Vol. 5, No. 2, pp. 126-138, Oktober 2018, DOI: http://dx.doi.org/10.21009/JKKP.052.04.

The document and its content have been removed from Jurnal Borneo Administrator, and reasonable effort should be made to remove all references to this article. 